\title{
(REHABILITATING HERITAGE PLACES) STRUCTURAL REPAIRS AND CONSERVATION WORKS FOR ASTOR KOLKATA, INDIA
}

\author{
Shalini Dasgupta ${ }^{1}$, Laurent Fournier ${ }^{2}$ \\ ${ }^{1}$ Principal Conservation Architect - Heritage Conservation \& Design Centre, New Delhi, India, hcdcdesigns@gmail.com \\ Visiting Faculty - School of Planning \& Architecture; Dept. of Architectural Conservation \\ ${ }^{2}$ Laurent Fournier - Laurent Fournier (Architecte D.P.L.G, France), architectural consultant based in Kolkata, lohabithi@gmail.com
}

KEY WORDS: Documentation, Structural repairs, Heritage Management, Conservation, Rehabilitation, Historic Interiors

\section{ABSTRACT:}

Kolkata, formerly known as Calcutta in English, is the capital of the Indian state of West Bengal and is located in eastern India on the east bank of the River Hooghly. The city was a colonial city developed by the British East India Company and then by the British Empire. Kolkata was the capital of the British Indian empire until 1911 when the capital was relocated to Delhi. Kolkata grew rapidly in the 19th century to become the second city of the British Empire. This was accompanied by the development of a culture that fused European philosophies with Indian tradition. The city has been known by many names "Cultural Capital of India", "The City of Processions", "The City of Palaces", and the "City of Joy". Problems related to rapid urbanisation started to plague Kolkata from the 1930s and the city remains an example of the urbanization challenges of the developing nations. The exercise included Archival research, Field surveys, Condition Mapping, structural evaluation and preparation of restoration \& conservation solutions along with post conservation management plan. The Major challenges encountered were identifying the correct consolidation techniques using modern technology and incorporation of modern services. The Documentation and Mapping was used as a significant tool to guide towards the structural consolidation, conservation and Management strategy of the complex.

\section{INTRODUCTION}

\subsection{Context}

Calcutta, the city of joy was established in the year 1686, as a result of the expansion plans of the British Raj. It was during those times that European powers were heading their way towards capturing the small villages of Sutanati, Govindpur, and Kalikata. Calcutta derived its name from the last of the village settlements of kalikata.

The city kept progressing until 1756, when Siraj-Ud-Daula (Nawab of Bengal) attacked and succeeded in driving the British away from the town. It was during that time that most of the British civilians had escaped, but a few of them were captured and imprisoned in a suffocating room. This incident has become a history in itself and was given the name 'Black hole tragedy'. In 1757, the following year, Battle of Plassey took place, in which Robert Clive took over the city by defeating the Nawab

The end of battle witnessed the establishment of Supreme Court in 1774, making Calcutta as the base of justice. Battle of Plassey saw the drain of wealth, which strained the Bengal's economy. The
period between
1820 and 1930
saw the growing
of seeds of
nationalism that
reached its height
in 1905, when
people stood
against rord
Curzon's plan
regarding the partition of Bengal. Rabindranath Tagore led the nationalist anti partition movements. The Partition was repealed in 1911, followed by the shifting of capital of India from Calcutta to New Delhi. In 2001, Calcutta was officially renamed Kolkata.

\subsection{The Astor}

The Astor hotel is Located at the heart of the Central Business and Retail District, the hotel is well-connected to most places of interest and curiosity in Kolkata. This property was originally a bungalow owned by Mr. Astor which later got converted into a lodge and subsequently a hotel in 1905 .

\section{Historical Timeline}

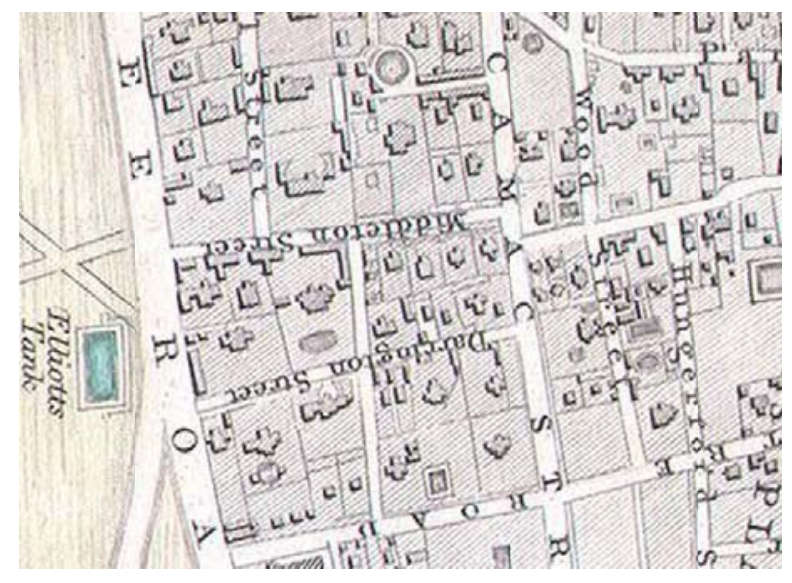

Figure 1 : The plot and surroundings are shown in an early map Chapman \& Hill, 1842 


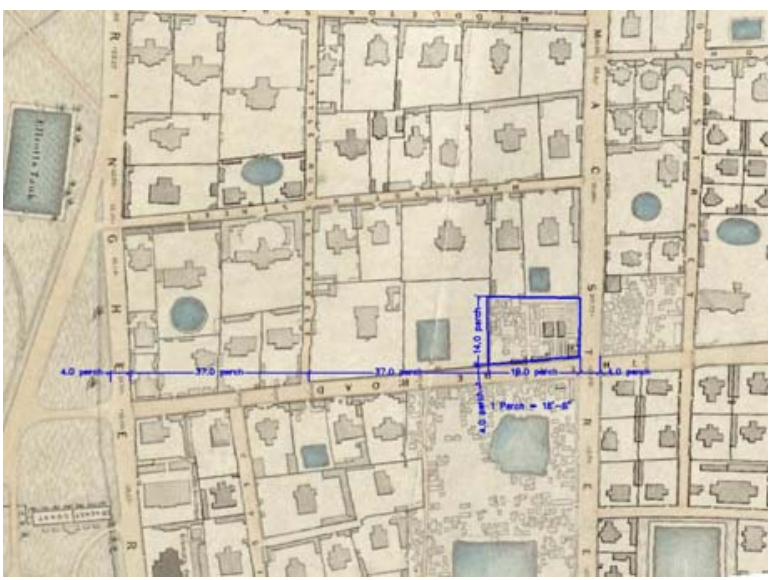

Figure 2: The 1858 map of park street kolkata

In 1858, the plot accommodates a "bustee" with mostly kaccha structures. The unit of measure is most probably the perch $=$ 16'-6', (Source: Simms map , 1847 revised 1858)

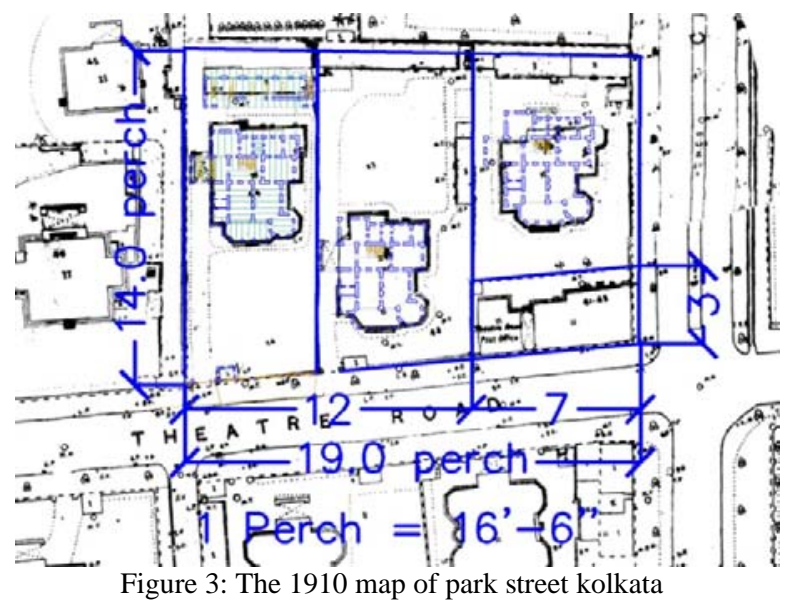

In 1910, the plot is shown sub-divided in 4 parts: the Theatre Road Post Office and 3 Bungalows. The bungalow at No. 44, Theatre Road belongs to Mr. Astor. Following the standard practice, the bungalow is served by an outhouse at the back (having stables in the ground floor and servant quarters in the first floor), and a gate-keeper's room.

Source: Cadastral map, 1909-10

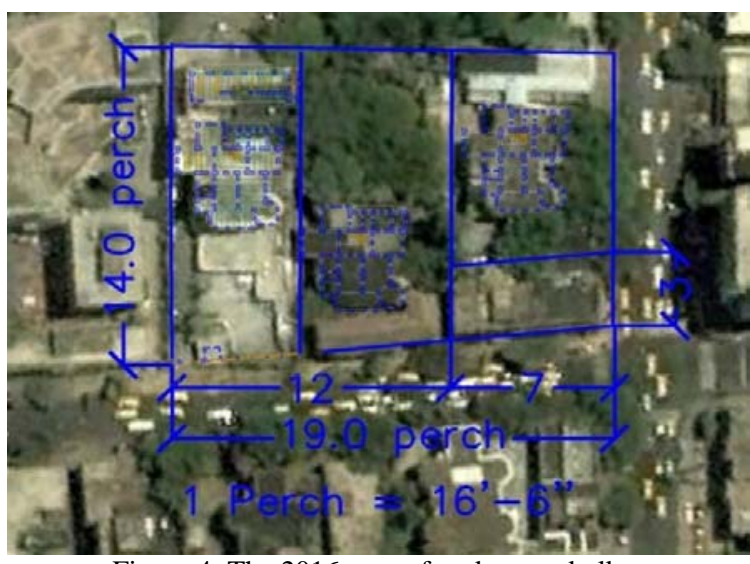

Figure 4: The 2016 map of park street kolkata
Today, the 3 original bungalows are still visible on this satellite picture (Google Earth May 2005).

Original ground floor around 1900:

1. Main Bungalow;

2. Out house at the back with stables and servants quarters;

3. Gate room.
Probable architectural plotting and initial room layout in the Ground Floor:

1. Plot: Divided in two equal squares and a leftover at the back, for the front garden, the house, and the service building respectively.

2. House: Inscribed in a square divided in 4 parts. The services are grouped in two narrow bays on the North and West, leaving the East and South fully open to the living rooms. The stairwell in the centre with its skylight, an office with direct access from the entrance, and a "picturesque" interplay of verandas and octagonal tower on the East and South facades, complete the composition in plan.

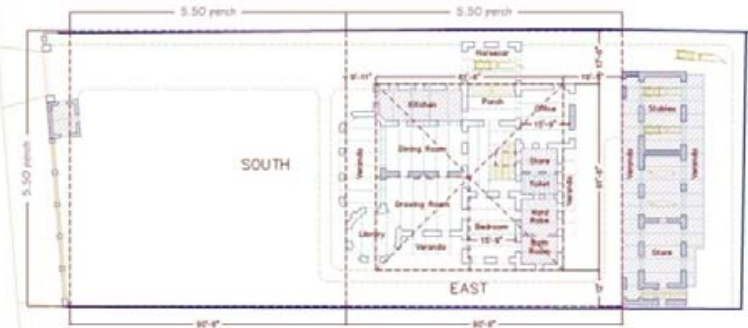

Evidence of vertical extension done in phases As in several other buildings of Kolkata's colonial period, the cornice of the horsecar porch is not horizontal. This could be because the

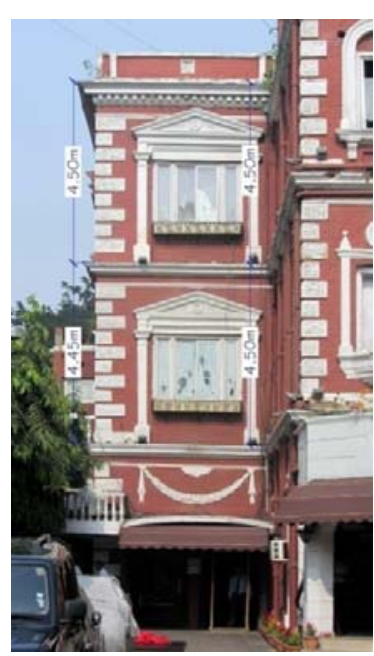
standardized strip foundations were the same everywhere but the more lightly loaded horsecar porch did not settle as much as the rest of the building during the initial settlement period. A few decades later, the first and second floor were added and remained horizontal, because the initial settlement had already taken place. Today, the non-parallel cornices are evidence of construction in phases, with long intervals inbetween. 


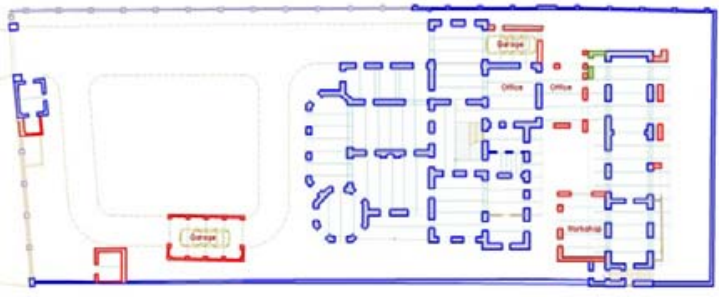

Constructions with 15'”-thick walls and steel joists, probably built before 1947:

1. Garage or office extension;

2. Office extension;

3. Store or workshop;

4. Garage;

5, 6. Store, guard's room

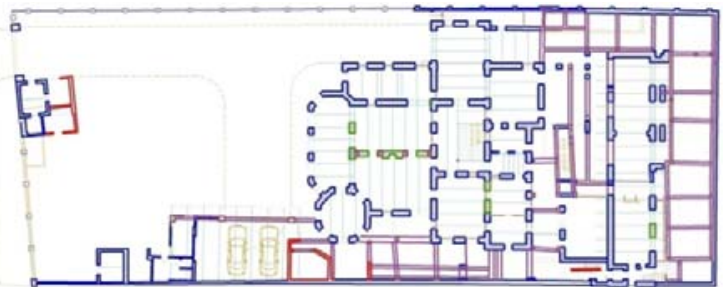

Demolitions and RCC constructions, probably done between 1947 and 1960:

1. The garage is extended on the North with new steel joists and a steel frame;

2. Gate building extension;

3. RCC frame construction (probably replacing light masonry structures, now vanished);

4. Change of the direction of the existing staircase;

5. New staircases ( $5 a \& 5 b)$;

6. Creation of a large room on the Ground Floor.

\subsection{Project \& Objectives}

The Aim of the project was structural consolidation \& rehabilitation of the property through conservation of its natural and cultural resources and, further develop the site in a manner which is appropriate to its cultural significance, thus promoting an 'enhanced visitor experience'.

\section{Typical status in 2011: Vertical Structure}
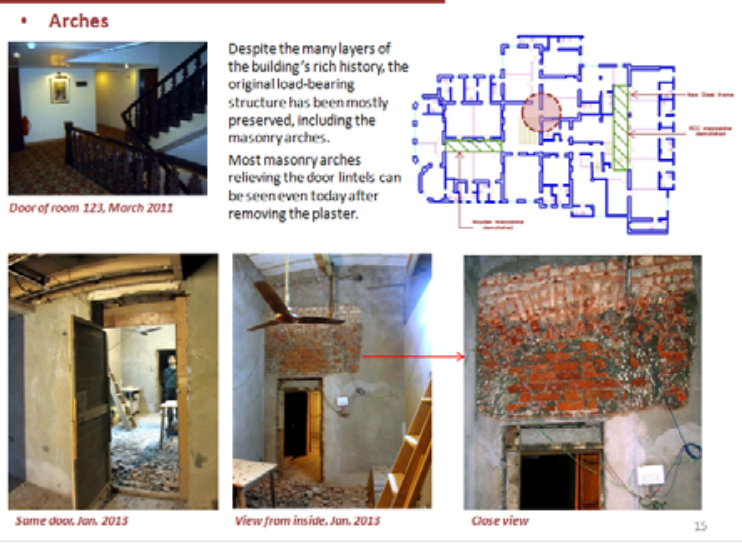

Figure 5: Site survey plan of the complex

\section{THE DOCUMENTATION PROCESS}

\subsection{Identifying the structural Problems}

\section{- Arches}

Despite the many layers of the building's rich history, the original load-bearing structure has been mostly preserved, including the masonry arches.

Most masonry arches relieving the door lintels can be seen even today after removing the plaster.
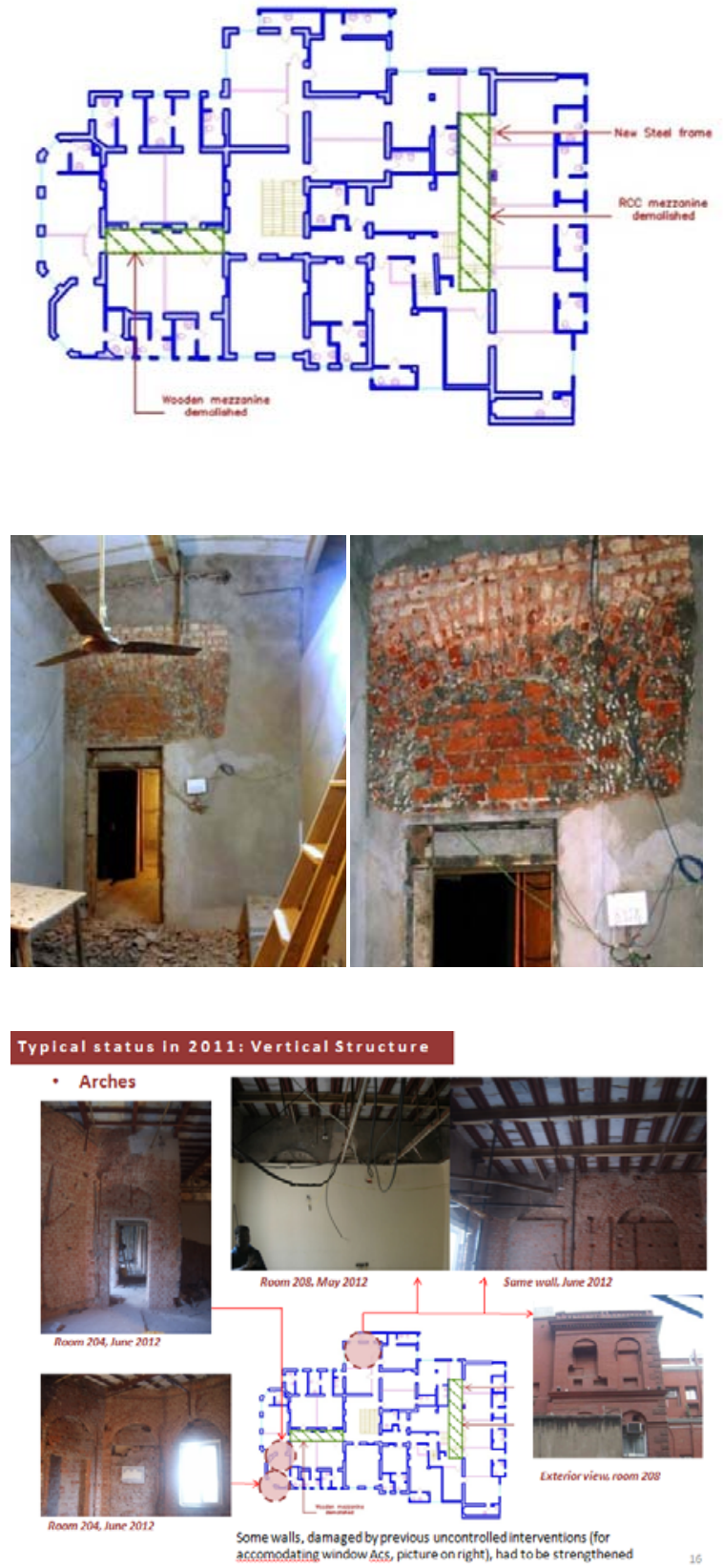

Some walls, damaged by previous uncontrolled interventions (for accomodating window Acs, picture on right), had to be strengthened 


\section{- De-cohesion of the building}

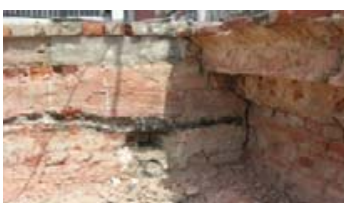

Condition of walls discovered after scrapping the plaster at roof level:

Extensive cracks and de-cohesion of the building (upto 2 inches of cumulated cracks at roof level, upto 1 inch at second floor level)

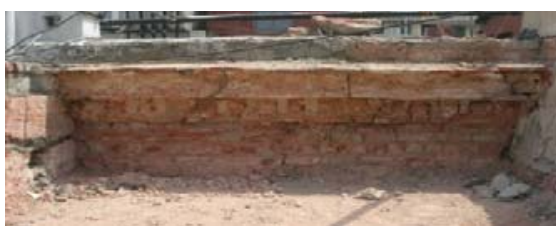

Evidence of ancient de-cohesion of the building: Ancient remediation by steel ties \& anchor plates at first \& second floor levels of the rotunda

\section{- Roof}

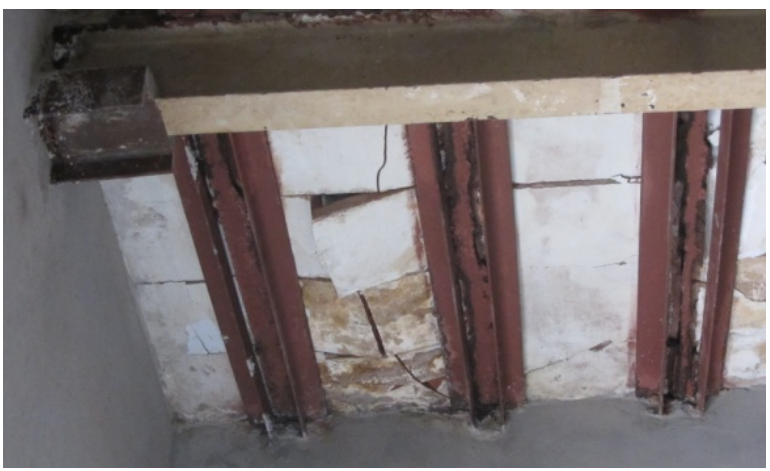

Oblique cracks seen above the false ceiling, old repair of roof "T-bars" already corroded, terra cotta tiles collapsing Investigations after removing the false ceiling:

Many cracks caused by differential settlement (less than 1 inchwide cracks), corrosion of the entire steel roof structure, lime concrete slab collapsing at some places.

\section{Status Summary}

\section{Building Services:}

- Old, dilapidated and unsafe under the present industry norms.

\section{Vertical Structure:}

- Original load-bearing structure mostly preserved, including the masonry arches.

- $\quad$ The building was experiencing a long-term overall de-cohesion (the walls were slightly drifted apart) which needs to be arrested for the safety of the building, particularly in view of the seismic risk.

- $\quad$ The original load-path has been altered by numerous alterations, big and small:

Gradual addition of new storeys on the former entrance porch and bathrooms;
Creation of large openings at various places in the ground floor;

Load-bearing pillars punched to make way for doors and window ACs;

Reinforced concrete mezzanine adding extra load on a weak wall in the annexe;

Many brick masonry partitions have been added in many places.

\section{Horizontal Structure:}

The original steel structure of floors at roof level and below the bathrooms was damaged and had been already repaired several times at some places. On the contrary, the floors which have been supporting neither bathrooms nor roofs were in overall good condition and easily repairable

\subsection{Assimilation of the Structure}

\section{Strengthening existing structure}

- Repairing the damaged floors and restoring the overall building cohesion

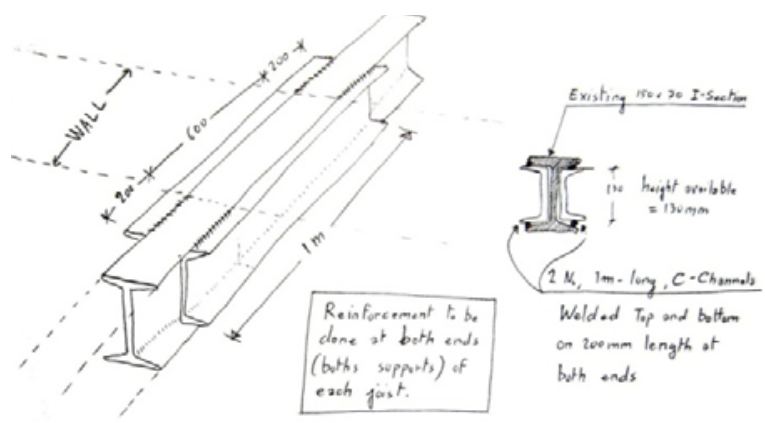

Splicing of steel joists where damage is localized at the joist supports

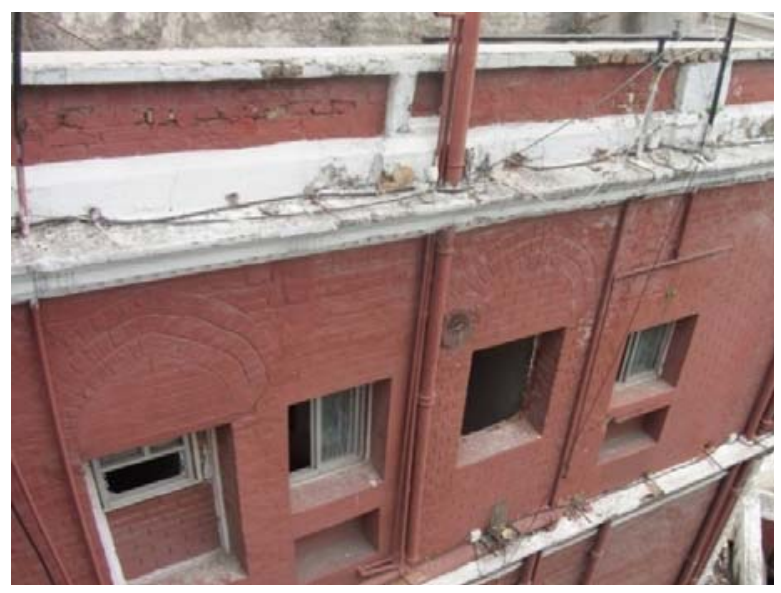

Steel anchors grouted in roof slab and in bathrooms slabs, ready for linking with horizontal ties 


\section{Restoring original features}

\section{Arches}

After demolishing the first floor wooden mezzanine that was unsafe because resting on 3"'-thick brick partitions, we have restored the load-distribution capacity of the load-bearing shear wall by re-constructing the arch that had been demolished when the mezzanine was made in the 1960s.

Taking support from the existing inclined brick layers at the spring points of the ancient arch, we have avoided the disturbance that a steel beam would have necessitated for creating its supports in the heavily loaded adjacent masonry pillars.
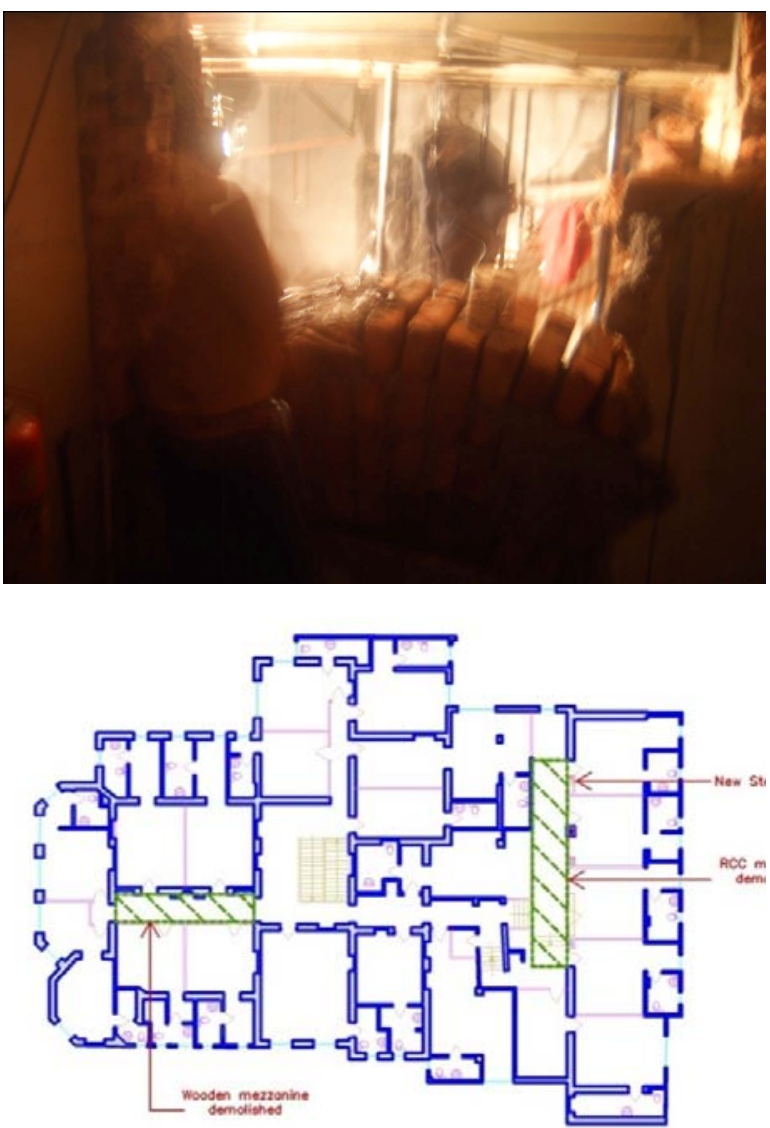

\section{- Skylight in the stairwell}

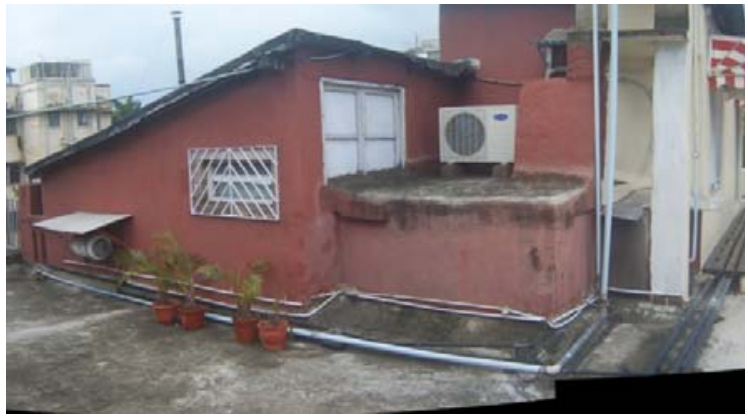

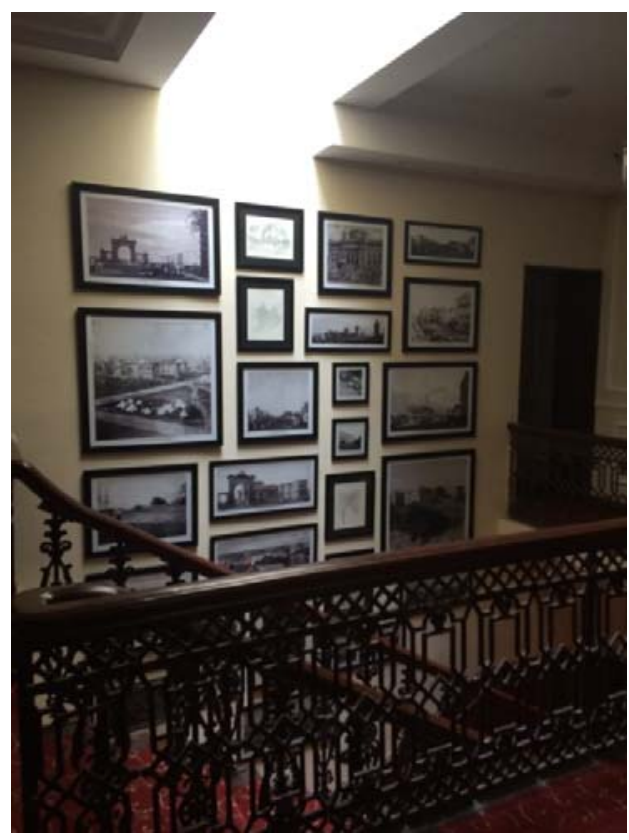

Today: After demolition of unsafe water tank and rotten old skylight, the existing opening is ready to receive the new skylight

- No modification of the original structure, restoration of the facade

\section{Ground floor and exterior}
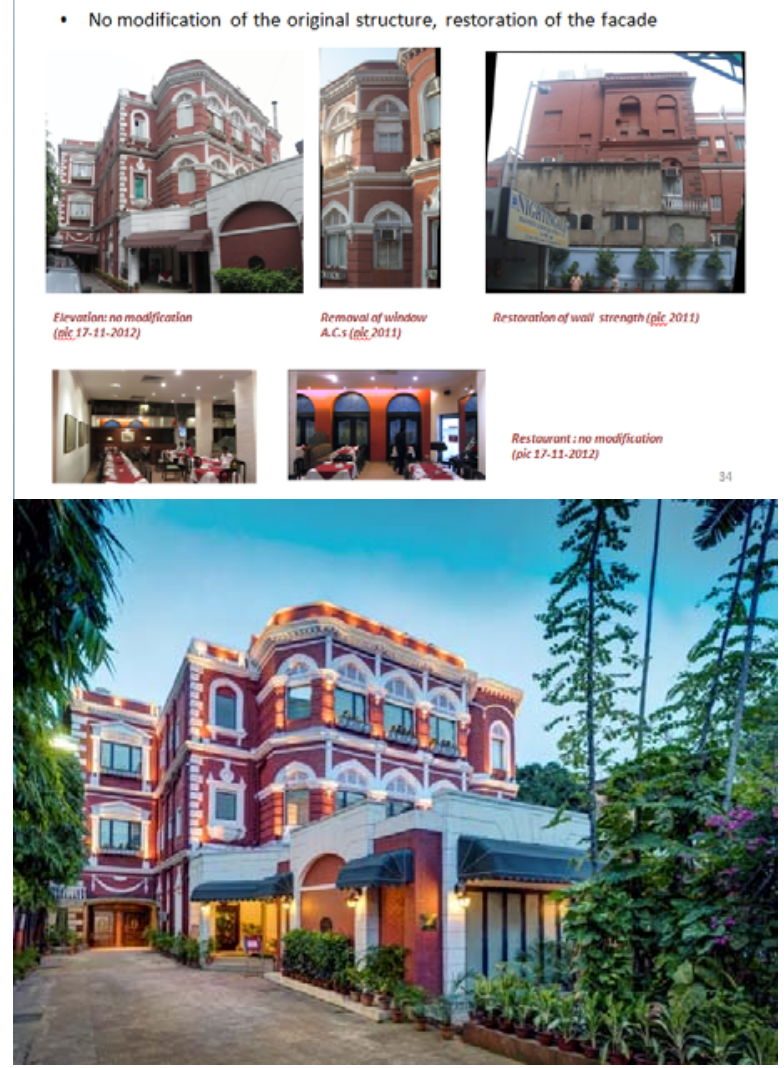
Before

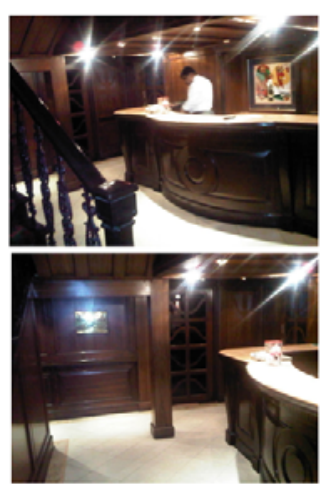

After

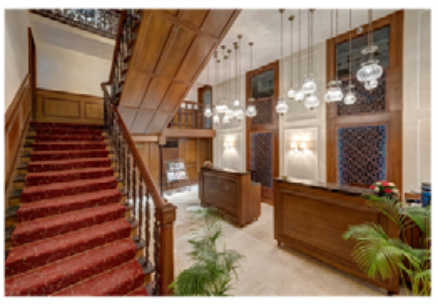

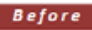
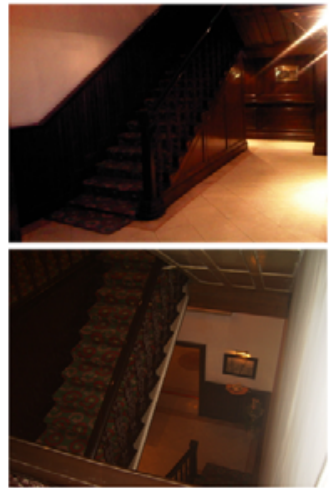

Before

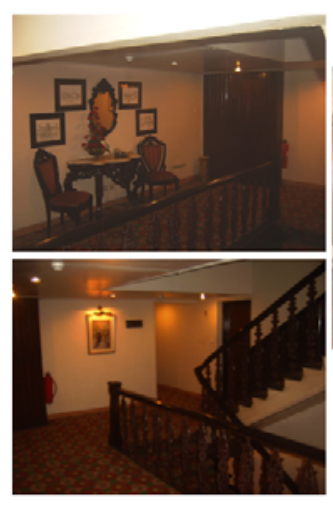

\section{CONCLUSIONS}

This exercise mainly focuses on the structural consolidation of deteriorated surfaces and elements of the historic buildings. The use of non-destructive analytical tools has been impressed upon as a complementary method to produce images that provide information regarding the interior and exterior surfaces.

The documentation process achieved the primary aim of producing heritage mapping and identifying defects in the historic structure, representative of the city's cultural heritage. It also created a digital database consisting of physical qualitative attributes data for future management and recording for posterity. The challenges faced while attempting the exercise were mainly due to financial and time constraint

The essential architectural approach was that in the entire operation, the existing building has been consistently considered as an asset and never as a liability. This has allowed the success of the operation within a limited time and budget.

The aesthetic of the interior has been achieved in spite of the unavailability -or unaffordability- of the traditional crafts and materials normally required (like seasoned teak wood, traditional carpentry, window panes and cabinet-making, iron and traditional blacksmithery, etc.).

We were finally successful in turning a shabby and crumbling maze of narrow, low-ceiling corridors and bleak rooms into a simple, harmonious, spacious and functional space, with a sense of elegance and luxury, while restoring truthfully the character of the original building. In fact, $99 \%$ of our collective challenge and effort has been on step-by-step repairing of the huge accumulation of errors and blunders that have been made in the course of the last 20-30 years, when the original bungalow was gradually turned into a hotel, without involvement of any architect or engineer, in an extremely low-cost and ad-hoc manner, and of course without long-term planning. We have removed tons of haphazard modern structures, reinforced concrete mezzanines, wooden mezzanines, flimsy steel structures, all very dangerous from the structural and fire point of views, and we have greatly improved the stability and fire safety of whatever remained from the original structure. We have done all this by preserving all the viable parts of the original structure (at least $95 \%$ of the original structure), in a reversible manner, while accommodating the $\mathrm{AC}$ and other services, within the budgetary, time and technical constraints of a commercial project.

\section{ACKNOWLEDGEMENTS}

The work presented here was undertaken by the team of Heritage Conservation \& Design Centre, New Delhi, India.. The Author would like to thank all officials of the Kolkata Municipal Corporation and their Heritage committee members for their help and valuable inputs whenever required.

\section{REFERENCES}

1. Mukerji, Dr. S.C. 1991. The Changing Face of Calcutta: An Architectural Approach. Government of West Bengal.

2. Gupta, Subhrangshu (May 17, 2003). "Job Charnock not Kolkata founder: HC Says city has no foundation day". The Tribune online edition. Retrieved 2006-12-17

3. O.P. Kejariwal The Asiatic Society of Bengal and the Discovery of India's past (Delhi: OUP) 1988 pp29-75

4. The Memoirs of William Hickey (London: Hurst \& Blackett) Vol.II (1918) pp154-5

5. D. Watt, Surveying Historic Buildings : Donhead, 2010.

6. H.E. Busteed Echoes of Old Calcutta (Calcutta) 1908 pp73106; H. Beveridge The Trial of Nanda Kumar 